\title{
Searching for a Cultural Home: asian American Youth in the EDM Festival Scene
}

\author{
$\because$ Feature Article $\longrightarrow$ \\ JUDY SOOJIN PARK \\ HARVARD UNIVERSITY (UNITED StATES)
}

\begin{abstract}
This article investigates the recent proliferation of Asian American participants in Electronic Dance Music (EDM) festivals with a particular focus on those organized by Insomniac Events in Southern California. As Insomniac's events aim to propagate an ethos of PLUR - Peace, Love, Unity and Respect-reminiscent of historical rave culture, these events promise a space where anyone, regardless of race, class, gender or sexuality, is accepted. Using an interview-based methodology paired with participant observation, I argue that Asian American youth's status as "perpetual foreigners" and subsequent desire for cultural belonging have motivated their participation in events promoted by Insomniac. Nevertheless, the Asian American participants I interviewed defined notions of belonging, authenticity and subcultural capital in the EDM festival scene in relation to suburban middle-class whiteness and in opposition to urban hiphop blackness. My research provides a much-needed study of nonwhite participants and how they negotiate their subjectivities in relation to the contemporary EDM festival scene.
\end{abstract}

KEYWORDS: Asian American youth, belonging, racial ideology, PLUR, electronic dance music, Insomniac Events

Judy SoojIn Park received her Bachelor's degree, Summa Cum Laude, in Social Studies with a focus on Identity and Inequality in the US at Harvard University. Her award-winning senior thesis was a study of how Asian American youth negotiate their subjectivities in relation to the contemporary EDM festival scene in Southern California with a focus on ideologies of race, class, gender and sexuality. $<$ judysoojinpark@gmail.com> 


\section{INTRODUCTION}

This article investigates the recent proliferation of Asian American participants in Electronic Dance Music (EDM) festivals with a particular focus on those organized by Insomniac Events in Southern California, such as Electric Daisy Carnival ${ }^{1}$ and the Wonderland series. Insomniac is unique among organizers of large EDM festivals in this region, such as HARD Events, as it appears to have fully embraced the historical rave culture and ideology of PLUR (Peace, Love, Unity and Respect). Insomniac's events not only emphasize a magical and utopian ambience with themes incorporating Alice in Wonderland and the Snow Queen, but Insomniac founder Pasquale Rotella has explicitly referred to PLUR in his social media accounts and has actively encouraged attendees to wear kandies, ${ }^{2}$ a defining symbol of PLUR in contemporary EDM festival culture (Rotella 2014; Sachs 2014). By propagating an ethos of PLUR, Insomniac's events promise a space where anyone, regardless of race, class, gender or sexuality, can experience cultural belonging and acceptance. Meanwhile, as Insomniac's festivals continue to become increasingly massive and commercialized, these events have attracted significant participation from groups beyond the middle-class white participants typically associated with the EDM festival scene. This newfound diversity of participants tests the egalitarian ethos of PLUR and provides an opportunity to examine how various groups negotiate their subjectivities in relation to the contemporary EDM festival scene.

This article is a preliminary study of this tension between the massive contemporary EDM festival scene and the ideology of PLUR, which purports that EDM festivals are free from identity-based boundaries or inequalities. Using an interview-based methodology paired with participant observation, I argue that Asian American youth's status as "perpetual foreigners" and subsequent desire for cultural belonging have motivated their participation in EDM festivals. Nevertheless, the Asian American participants I interviewed defined notions of belonging, authenticity and subcultural capital in the EDM festival scene in relation to suburban middle-class whiteness and in opposition to urban hip-hop blackness. These experiences further perpetuated dominant understandings of race and the normalization of whiteness amongst my informants. ${ }^{3}$

EDM festivals are a meaningful place to analyze identity and belonging, as their roots can be traced back to the historical rave scene providing marginalized groups with alternative spaces of transgression. House music first developed in predominantly gay black clubs in Chicago in the 1980s, which provided a pressure valve, especially for clubgoers facing the dual oppression of racism and homophobia (Silcott 1999: 22). Soon house music became popular in the UK after several British DJs encountered the music in the open-air disco scene of Ibiza in the summer of 1988, often referred to as the "Summer of Love". These DJs sought to replicate this "hippie-ish, under-the-stars, beautiful open vibe", together with variations of house music and the euphoric effects of the drug ecstasy also encountered in Ibiza, in London (Silcott 1999: 31). Taking place in clubs, warehouses and even fitness centers, these dance parties came to be called "raves". Although the British rave scene was far 
removed from Chicago house, it similarly provided a space of transgression-in this case, for British youth to escape from the cultural repression and economic realities associated with the Thatcher era.

The concept of raves quickly spread beyond the UK and returned to the US, where the concept of PLUR flourished in various locations, but particularly in California where the legacies of the 1960s counterculture persisted. The first recorded raves were in Los Angeles and San Francisco in the late 1980s, hosted by British expatriates (Reynolds 1998: 149). Throughout the nineties, the US rave scene developed in different forms in various locations. Importantly, most of these scenes came to be identified with middle-class white youth with house music's connection to the Chicago gay black scene largely forgotten. This whitening of the scene was facilitated by a moral panic and news coverage of white middleclass youth partaking in excessive drug use in unlicensed dance parties. By the early 2000s, police crackdowns had largely corralled the rave scene into conventional nightclubs and the live event industry. The latter grew steadily and began to gain notable traction in the late 2000s. In 2010, Insomniac's Electric Daisy Carnival (EDC) attracted wide news attention due to a fifteen-year-old female attendant dying from overdose of ecstasy, which caused the city of Los Angeles to place a moratorium on all remaining events for the year. Ironically, my interviewees believed that the news served as publicity for EDC, which moved to Las Vegas in 2011 as a three-day festival attracting a record of more than 230,000 participants.

Despite rave's roots in providing a space of belonging and acceptance for marginalized groups, few scholars have focused on nonwhite participants' negotiations of race or class in either the rave or EDM festival scenes. In fact, there seems to exist a clear tension between scholars' claims that raves erase identity-based boundaries and stereotypes, and their lack of attention to how nonwhite participants negotiate this "erasure". Most ethnographic studies have focused on ways raves provide white middle-class participants with socially distinct identifications and an alternative space of peace, love, unity and respect (Thornton 1996; Collin 1997; Reynolds 1998; Hutson 2000; Measham et al. 2001; Hill 2002). Notable exceptions include Fikentscher (2000) and Buckland (2002), although my research provides more recent analysis, focusing specifically on Asian American participants, a largely overlooked group in EDM cultural studies.

Therefore, my research makes two key contributions. First, it provides a much-needed study of the contemporary EDM festival scene focusing on how nonwhite participants negotiate their subjectivities in relation to the scene. In particular, the dominant depiction of Asian Americans as "honorary whites" offers a unique opportunity to question the extent to which Asian American participation reinforces, obfuscates or undermines the middleclass whiteness of EDM festivals. Second, my research seeks to increase the visibility of Asian American youth and their engagements with popular culture, which has been largely neglected in ethnographic research and theory. ${ }^{4}$ As Lee and Zhou note, "Asian American youth as a group have been almost entirely omitted from research on youth and youth culture in the U.S." (2004: 9). I argue that the academic negligence of Asian American youth's involvement in popular culture further perpetuates their status as "perpetual foreigners". 
After discussing my research methodology, I trace the history of dominant white depictions of Asian Americans, which have consistently portrayed Asian Americans as perpetual foreigners, inassimilable to the white American culture. Then, I analyze how the Asian American youth I interviewed have turned to the EDM festival scene for its promise of an egalitarian utopia, exemplified by the ethos of PLUR particularly in Insomniac's events. Finally, I argue that despite the rhetoric of racelessness, EDM festivals are signified by middle-class whiteness defined against lower-class hip-hop blackness, which my interviewees imagined to be urban lifestyles full of crime and gang activity.

\section{Research Methodology}

Most of my data consist of in-depth interviews with Asian American EDM festival participants in Southern California, paired with contextual information from participantobservation of the 2014 White Wonderland organized by Insomniac. Over the course of eight months from May to December 2013, I conducted thirty-eight interviews with youth who self-identified as Asian American and have attended at least three EDM festivals in Southern California, although thirty-one interviewees have attended more than eight. I interviewed twenty-one males and seventeen females. All interviewees were above the age of eighteen and the average age was twenty-three. I used the snowball sampling method by first asking my high school and college networks in Southern California and then my interviewees for introductions to Asian American EDM festival participants. I used the open-ended and semi-structured interview method, as this study focuses on Asian American youth's subjective understandings of identity and belonging. My interviews ranged from a half-hour to an hour and a half.

I allowed interviewees to self-identify as Asian American rather than imposing a formal definition, because my research focuses on Asian American-ness as a cultural identity-an individual's sense of belonging within a group based on his or her understanding of the group's culture. This decision relies on the assumption that racial categories such as Asian Americans are social constructions that are historically contingent and unstable in their boundaries. As a result, I interviewed three individuals who identified as Asian American and as half-Asian or multiracial. The majority of interviewees, thirty-three of the thirtyeight, ethnically identified as Chinese, Taiwanese, Korean, or Vietnamese, which, according to my informants, reflects the popularity of EDM festivals among these ethnic groups. Thus, it is important to note that the Asian American cultural identity under discussion in this article is based on the specific understandings and experiences of my informants from limited ethnic groups, rather than a universal definition. Based on my interviews, I would synthesize their understanding of Asian American-ness to be associated with middle-class East Asian (more specifically Chinese, Taiwanese and Korean) and Vietnamese youth living in suburban Southern California. Nevertheless, informants of other ethnicities (South Asian, Filipino, Japanese and multiracial) self-identified with the Asian American classification largely through their identifications within East Asian or Vietnamese social groups. Though I do not argue that the diverse narratives and experiences of various ethnicities within 
East Asian, South Asian and Southeast Asian groups can be collapsed into one category, I suggest that the broader "Asian American" group is the most relevant to discussions of race in the EDM festival scene. Most of my interviewees categorized racial groups in the scene as whites, blacks, Latinos and Asian Americans, defining Asian Americans as inclusive of individuals from East Asian, South Asian and Southeast Asian groups.

I paired these interviews with participant observation at six EDM events including the 2013 White Wonderland, an annual New Years Eve music festival organized by Insomniac. My experiences at White Wonderland helped to contextualize my interviewees' experiences and support my interview findings. I experienced firsthand the magical and fantastical production by Insomniac, including white pillars surrounding the stage, snowflakes and chandeliers hanging from the ceiling and rays of laser light covering every corner of the dance floor. As noted by several interviewees that "White Wonderland has the most Asians" due to its location in Orange County with a large Asian American population, I found that more than half the participants were Asian American. Furthermore, most of the Asian American participants I saw appeared to arrive in predominantly Asian American groups without significant interaction with those outside their groups. My lack of direct exposure to music festivals beyond White Wonderland serves as a limitation of my study. Nevertheless, it is important to note that my research question focuses on racial ideologies and their interplay with the ideologies of the EDM festival scene rather than racial performance. I focused my initial research on interviews as they allowed me to analyze how these ideologies influenced Asian American participants' understandings of their experiences in the EDM festival scene and of their Asian American identities. I plan to conduct further ethnographic research to support the preliminary findings presented in this article.

\section{Researcher Positionality}

Another limitation of my study is the extent to which my position as a researcher influenced interviewee responses. I am not an insider to the scene, as I did not listen to EDM extensively and had never attended a festival before I began my research. I also never experienced the influence of drugs, which various scholars (Collin 1997; Reynolds 1998; Hutson 2000; McCall 2001; Hunt et al. 2010) and many of my interviewees believe are an important aspect of the EDM festival culture. On the other hand, my status as an outsider to the scene allowed me to ask festival participants a wide range of questions relating to their observations of other participants, as well as their perspectives on the PLUR-based culture, drug use, attire and sexual expressions.

Although I am an outsider to the scene, my interviewees seemed to consider me an insider in other ways. ${ }^{5}$ Given that I am an Asian American young woman from Southern California, my interviewees seemed excited to share relatable experiences ranging from the high schools they attended to the Asian market where they first heard trance music. In particular, my young age seemed to put interviewees at notable ease, as indicated by their use of slang and profanity, candid discussions of their sexual or illegal experiences 
and expressions of internalized stereotypes of race and class that have become critical to my analysis. In particular, my interviewees seemed to be very comfortable sharing their internalized stereotypes of Asian Americans and even suggested that I would know about the academic pressures or strict parents because I was also Asian American. On the other hand, my identity as a heterosexual woman seemed to limit some interviewees' responses when discussing topics of gender and sexuality. Some instances, however, such as when my male interviewees would noticeably hesitate or filter their perspectives on female participants, served as powerful moments for analysis.

\section{Perpetual Foreigners without a Cultural home}

In this section, I argue that despite the seemingly contradictory nature of various dominant portrayals of Asian Americans, such as the "yellow peril" and "model minority", Asian Americans are consistently portrayed as "perpetual foreigners" who are unassimilable to the dominant white American culture. These depictions have created a complex relationship between Asian Americans and the mainstream American culture. Not only do these "controlling images" (Hill Collins 2000) circulate through popular culture and media, but they have also largely excluded Asian Americans in popular culture and media. Although whites have occasionally depicted Asian Americans with similar characteristics as middle-class whites when it serves their interests to do so, the persistent portrayal of Asian Americans as perpetual foreigners ultimately denies Asian Americans access to the privileges of middle-class whiteness.

\section{From "Yellow Peril" to "Model Minority"}

Though dominant portrayals of Asian Americans have shifted from the "yellow peril" in the late 1800s to the "model minority" in the 1960s, this transition was initiated by whites to advance white interests. The first dominant depiction of Asian Americans, particularly Chinese immigrants to the West Coast in the late nineteenth century, was their portrayal as foreign threats to the American nation and family. Often referred to as the "yellow peril", white Americans' fear of this threat was framed not only in racialized imperialist terms of "earlier fantasies of exotic but distant Asia", but also in gendered terms of Chinese Americans jeopardizing traditional white gender roles (Lee 1999: 9). Chinese American men were depicted as cheap "coolie laborers" who stole jobs from white male laborers and undermined the white man's duties to his family. Chinese American women were depicted as prostitutes who threatened the "purity" of white womanhood (Lee 1999: 9-10). These fears eventually culminated to the 1875 Page Act: the first federal restrictive immigration law that prohibited the entry of "undesirable" immigrants from Asia, particularly those perceived likely to become forced laborers or prostitutes.

Popular representations of Asian Americans shifted from the undesirable coolie laborers and prostitutes in the late nineteenth and early twentieth centuries to the "model minority"

in the 1960s, "at the peak of the civil rights and ethnic consciousness movements" (Lee and 
Zhou 2004: 17). In this context, whites used depictions of socioeconomically successful Asian Americans to deny the existence of racial inequalities and to blame other nonwhite groups, such as blacks and Latinos, for being culturally unfit or unwilling to attain success (Lee 1996, 2005). Various scholars have critiqued this stereotyping for obfuscating racial inequalities, hindering nonwhite solidarity and alienating Asian Americans who do not fit into the successful "model minority" mold. Some scholars, however, have overlooked the interrelated link between depictions of Asian Americans as the "model minority" and the "yellow peril". For example, Lee and Zhou argue that the model minority stereotype "marked a significant departure from the portrayal of Asian Americans as aliens and foreigners" (2004: 17). Nevertheless, I am sympathetic with the view that "the model minority and the yellow peril are actually continuous images" in that both images have depicted Asian Americans as perpetual foreigners who could be easily stereotyped as exotic creatures in order to advance white interests (Kibria 2002: 132). ${ }^{6}$ Despite the "model minority" myth characterizing Asian Americans with seemingly positive and white-like qualities such as being hardworking, disciplined and success-oriented, it also suggests that Asian Americans are ultimately unlike whites in that they are too hardworking, disciplined and successoriented, or that they possess only these qualities. Both the "model minority" myth and the "yellow peril" alienated Asian Americans as uninvited guests to the US who threatened the economic security of whites.

\section{Representations in Popular Culture and Music}

The link between the "model minority" myth and the "perpetual foreigner" archetype is particularly pronounced when discussing representations of Asian Americans in popular culture. Media depictions have powerful implications by serving as "controlling images" that disseminate dominant ideas about marginalized groups that often justify their own oppressions (Hill Collins 2000). Not only is popular mediation of Asians and Asian Americans scant, but even the few existing images are limited in the complexities of their representation: the overly sexualized "Lotus Blossom Baby (a.k.a. China Doll, Geisha Girls, shy Polynesian beauty, et al.) [or] the Dragon Lady (Fu Manchu's various female relations, prostitutes, devious madams)" for Asian women and the desexualized "egghead/wimp, or... the kung fu master/ninja/samurai” for Asian men (Fung 2005: 237).

In popular music, Asian Americans lack not only representation in the number of artists, producers and DJs, but also a mainstream sound or scene that they can call their own (Lee and Zhou 2004: 19). Granted that South Asian bhangra music has experienced popularity in the US and some incorporation into popular music (Maira 2002), East Asians and Southeast Asians, who composed most of my interviewees, have not experienced as much success. ${ }^{7}$ For example, my interviewees noted that East Asian American artists seem to experience difficulty gaining sustainable success with white audiences, with the exception of "one-hit wonders like 'Gangnam Style' or 'Like a G6". 
This exclusion of Asian Americans in popular music reflects both the "model minority" and "perpetual foreigner" stereotypes. The "model minority" myth suggests that Asian Americans prioritize stable socioeconomic success over cultural and political engagements and that they lack the creativity necessary to become successful artists (Yu 2001: 189). The "perpetual foreigner" stereotype largely prevents white audiences from considering Asian American artists as American artists in the first place. In turn, the lack of Asian American representation in popular music further perpetuates the dominant notion that they are unassimilable to American culture. As Robert Lee argues, "the 'common understanding' of the Oriental as racialized alien...originates in the realm of popular culture, where struggles over who is or who can become a 'real American' take place" (1998: 5). I argue that the recently popularized EDM festival scene has also become a valuable place to frame discussions of who can belong as a "real American". As revealed throughout my interviews with Asian American participants, the scene perpetuates the myth that it is an egalitarian utopia while falling short of true racial equality and acceptance. This myth serves to further the dominant obliteration and denial of racial inequality in the US today.

\section{BELONGING Through EsCAPE}

In this section, I analyze how my interviewees' participation in the EDM festival scene relates to their Asian American identities and desire for cultural belonging. I argue that these discussions reflect a paradoxical understanding of the relationship between their Asian American identities and their participation in the scene. My interviewees claim that the EDM festival scene provides Asian American participants with access to mainstream American culture, yet the scene also represents experiences they consider antithetical to their Asian American backgrounds.

\section{SEARCHING FOR BELONGING}

The common thread throughout the history of the rave scene, despite all of its reappropriations, relocations and resurgences, is that raves represented spaces of belonging and acceptance to participants who have felt socially marginalized. The focus and definition of this marginalization has shifted in the US, particularly as rave culture, originating in gay black communities, has been reappropriated by middle-class white youth who identified themselves as social outcasts. In contemporary EDM festivals, particularly those organized by Insomniac, this promise of belonging and acceptance persists through the ideology of PLUR. Many participants believe PLUR connects the EDM festival scene with historical rave culture, or rather, their utopian imaginations of this culture. In fact, the majority of my informants used the word "rave" interchangeably with an "EDM festival" despite the clear differences in scale, production and culture of these two scenes. As EDM festivals have grown increasingly massive and its participant-base increasingly diverse, the juxtaposition between the ethos of racial inclusion symbolized by PLUR and the racialized groupings of participants creates a unique opportunity to analyze how nonwhite participants negotiate their subjectivities in relation to scene. 
Among my key questions to interviewees was why they believed Asian American participants were drawn to the EDM festival scene. A surprisingly high number of responses invoked Asian American youth's desire for cultural belonging and the rave scene's historical function of providing a welcoming space for society's outcasts. Elise, ${ }^{9}$ a twentytwo-year-old Korean American, grew up in a predominantly Asian American community where more than eighty-percent of the students at her high school were Asian American. In response to my inquiry, she stated, "I feel like a lot of Asians feel the need to fit in just because, you know, we are from a different country". By asserting that "a lot of Asians...are from a different country", even when she herself was born in the US, Elise seems to have internalized the dominant depiction of Asian Americans as perpetual foreigners who "feel the need to fit in". Later in the interview, she connects this desire for belonging with the PLUR-based culture of EDM festivals:

I think a lot of people that are into electronic music tend to be like introverted... like not the most popular people at school and stuff, so I feel like they feel accepted when they go [to EDM festivals] cause they're not feeling judged or anything... It's easy for them to make friends there, so I think that's what appeals to a lot of Asians.

Elise implicitly draws the parallel between Asian American youth and the introverted and unpopular white youth associated with the historical rave scene, suggesting that both groups seek a cultural scene that provides them with an alternative reality of belonging and acceptance.

Greg, a twenty-one-year-old Chinese American, echoed this belief that EDM festivals provide a space for Asian Americans to experience belonging, although his experiences were different than Elise's in that he grew up in a predominantly upper-middle-class white neighborhood in Ventura County. Noting that he has "personally felt racial discrimination" in his life, Greg stated that the EDM festival scene provided him and other Asian Americans with a sense of belonging away from the dominance of the popular white kids in school:

At least all or most of the Asian Americans that I've seen growing up in high school or middle school, they always wanted like a sense of belonging, to belong to something, whether they found like electronic music or something... For the most part, Asians, they're always like, 'Oh, he's probably all weak, can't protect himself.' He's always picked on so it's like to belong, like having a sense of family.

This imagery of "family" recurs regularly in the EDM festival scene and seems to be another legacy of the historical rave scene's communal and uniting power. Many interviewees called the groups with whom they attend EDM festivals, "rave families" and the people who first introduced them to the scene, "rave moms" and "rave dads". My interviewees' use of the metaphor that a "rave" is one big family suggests that they feel a deep connection with other participants who provide protection from the social dominance or bullying of the outside world. Yet, as I argue throughout the article, this metaphor of the family paints an overly idealistic picture of the contemporary EDM festival scene that is divided along racial and class lines. 


\section{FOLLOWING TRENDS}

In addition to the desire to find belonging, my informants also expressed a closely related belief that Asian American participants attended EDM festivals to "follow a trend". Charles, a twenty-two-year-old Vietnamese American, stated that Asian American youth began attending EDM festivals "because it's a fad. Yeah, I feel like Asian American culture, like, they're really heavily influenced by trends and fads, you know, what's in". When I asked Charles why he believes that the "Asian American culture" is heavily influenced by fads, he replied, "I have no idea. It's always been like that as far as I've seen, like when a new big restaurant comes out or when boba ${ }^{10}$ came out... It's like the sense of being included, you know"? Several other interviewees made similarly broad claims that Asian Americans are trendier than other racial groups. These perceptions highlighted these interviewees' beliefs that Asian American youth participated in EDM festivals to fulfill their desire for belonging.

A question that emerged from these conversations was whether Asian American participants believed that these trends, including EDM festivals, were started by whites or by other Asian Americans. The responses were divided. Elise provided a nuanced answer to this question, stating that "a raver identity is like something that makes you different from that average American, but at the same time... kinda ties you to the other Asians". In other words, Elise suggests that Asian American participation in EDM festivals serves the dual purpose of adopting the "raver identity", which they considered to be alternative to the mainstream and developing connections with other Asian American participants. A useful concept with which to analyze this phenomenon is subcultural capital, which Sarah Thornton (1996) defines as the status of "hipness", composed of cultural knowledge and commodities that participants of "subcultures" adopt in order to distinguish themselves from the mainstream culture and other subcultures. In other words, Elise seems to believe that Asian American participants reacted to their need to "fit in" to mainstream white America by "standing out", especially as they do not have access to dominant means of achieving popularity. Classifying the massive and commoditized EDM festival scene as a "subculture" may be closer to the participants' imaginations than reality, yet my interviewees firmly believed that Asian American participants adopted the unique "raver identity" to obtain a status of "hipness", as well as to become connected to other Asian American youth in the scene.

\section{Escaping From "Asian AMERICAN IDENTITIES"}

Despite claiming that EDM festivals provide a sense of belonging for Asian Americans, my informants paradoxically believed that EDM festivals also provide an escape from their Asian American identities. When I asked Irene, a twenty-one-year-old Taiwanese American, if she thought her experiences as an Asian American motivated her decision to attend EDM festivals, Irene responded that "parental restrictions", which have been a "big part of [her] life", motivated her participation. Invoking dominant depictions of Asian Americans as 
the model minority, Irene suggests that "parental restrictions" are an essential part of her understanding of the Asian American identity:

I think at raves, there's a contrast from being Asian, because, you know, it's not like that strict, restraining curfew, being home by ten... Like Asians, you can't really do that and get kicked out of the house, that sort of thing? So yeah, it's just like, I think because it's such a stark contrast from being an Asian. It's the freedom (emphasis mine).

Irene considers her participation in EDM festivals to be antithetical to "being an Asian" and suggests that EDM festivals open up the opportunity to free herself from her Asian American identity. Several interviewees also noted that EDM festivals provided them with the freedom and escape from strict parents, which they understood to be central to their identities as Asian Americans and parallels dominant white depictions of Asian Americans as the model minority.

Anthony, a twenty-one-year-old Vietnamese American, takes this idea of escaping from Asian American-ness further to argue that Asian American participants, including himself, have turned to EDM festivals in order to assimilate into whiteness, in contrast to Elise's earlier statement that Asian Americans became connected to each other through their participation. Although Anthony, like Elise, went to a predominantly Asian American high school, he notes that the most popular kids in school were white. He first heard about EDM festivals from several of these "popular" white girls, who he said he was "obsessed with" and "wanted to be their friends". He further stated, "Basically, that's why I was trying to hang out with them and trying to like assimilate into their whole white culture". When Anthony saw some of these girls posting about an upcoming EDM festival on their social media accounts, he states, "I was so intrigued and I wanted to be popular and I wanted to be cool, so I started like looking into it". It was only because of his desire of wanting to become as popular as these white girls and "assimilate into white culture" that he first began attending EDM festivals. Anthony extrapolates from his experiences to conclude, "Asians are trying to assimilate and copy white people, so they try to do the same thing". Anthony suggests that even though he attends EDM festivals with predominantly Asian American groups, he is entering a space that signifies a type of whiteness that he perceives to be "cool" and seeks to adopt.

\section{Unmasking the Middle-Class Whiteness of EDM Festivals}

In this section, I evaluate the ideological myth that the PLUR-based EDM festival culture is equally welcoming to and accepting of all identities. I argue that the EDM festival culture is dominated by middle-class whiteness, as whites predominantly control ideologies of authenticity and belonging within the scene. It is important to note that I do not base my argument merely on the racial demographics of EDM festival participants. Instead, I seek to highlight the racialization of EDM festivals, or the process of ascribing a race to the scene, by analyzing which groups control and represent the "raver identity" related to the EDM festival culture. First, I discuss how my informants negotiate the idea that most of the "main 
characters" of EDM festivals, including event producers, DJs and participants, are white despite the EDM festival's claims of being raceless spaces. Then, I argue that authenticity and belonging in the EDM festival scene are represented and dominated by middle-class whiteness. Lastly, I demonstrate how my informants understand EDM festival culture as being antithetical to what they believed to be urban black hip-hop culture.

I wish to highlight my interviewees' practice of "strategic ignorance", which Alison Bailey (2007: 88) defines as "a form of knowing that uses dominant misconceptions as a basis for active creative responses to oppression". In other words, instead of simply accepting or denying dominant white depictions of Asian Americans, Asian Americans may resist creatively by adhering to certain depictions when it serves their interests to do so. For instance, Asian Americans' internalization of their status as the model minority and its association with work ethic and ambition can be useful for improving their educational and vocational prospects. It allows them to benefit from their relatively closer association with middle-class whiteness and to disidentify themselves from the oppressions of other nonwhite groups. In the context of the EDM festival scene, strategic ignorance allows Asian American youth to justify their participation in a scene dominated by middle-class whiteness through their firm belief in the cultural similarities between whites and Asian Americans, as well as culturally racist understandings of other nonwhite groups. This section also highlights my informants' agency amidst the dominant racial structures and ideologies, as well as their statuses as "oppressed<->resisting subjects", simultaneously oppressed, resisting their oppression and oppressing other groups through cultural racism (Bailey 2007: 83).

\section{"White PEOPLE ARE STILL THE MAIN CHARACTERS"}

Although most of my interviewees adhered to the ideology of PLUR to claim that they do not associate EDM festivals with any particular race or ethnicity, a few individuals explicitly noted the scene's white dominance. When asked if she associates EDM festival culture with a racial group, Jen, a twenty-year-old Taiwanese American, stated, "even though I always go with Asian Americans, I would still say I think of white people for raves. The reason is because when all those events put up photos, it's always like white people photos. Like white people are still generally the main characters... Attendees, DJs are generally white people". Jen suggests that media images serve a powerful role in ascribing whiteness to the EDM festival scene for both participants and outsiders, regardless of whether the images accurately represent the firsthand experiences of participants. These images similarly echo the news coverage of the American rave scene in the nineties, which triggered the moral panic around middle-class white youth excessively using drugs and made middle-class white youth the main characters despite other racial groups participating in the scene.

Annie, a twenty-year-old Taiwanese American who attended the same international high school as Jen in Taiwan, echoed a similar belief in the dominant whiteness the EDM festival scene. When asked why she thinks EDM festivals appeal to Asian American youth, 
Annie responded, "I feel like the type of Asians they attract are Asians who are more Westernized... I don't wanna use this word, but I definitely don't see many 'fobby' ${ }^{11}$ Asians at raves at all". Annie's statement reflects a binary understanding of Asian Americans as the "Westernized Asians" and "fobby Asians", distinguished by their abilities to assimilate into white cultures. In fact, Annie seems to use the word "Westernized" as a euphemism for culturally white. When pressed further about why there are not as many black or Latino participants at EDM festivals who may be just as "Westernized" as Asian American youth, Annie responded hesitantly, "Oh yeah, hm... I don't know, I feel like, I feel like when you, um, listen to hip-hop and rap and stuff, like the image of black people is just so strong and I feel like that's kinda the same thing for EDM. Like for EDM, the image of white people is very strong so..." This statement not only places hip-hop blackness and EDM whiteness as polar opposites of each other, but it also implies that the aforementioned "Westernized Asians" are better able to identify with the whiteness of the EDM festival scene than black or Latino youth, a practice of strategic ignorance which places Asian Americans higher on the racial totem pole than other nonwhite groups.

Although Jen and Annie were two of the few interviewees who explicitly noted the association of EDM festivals with whiteness, my other interviewees' discussions revealed that the "main characters" in the scene are dominated by whites. Although there are no official statistics on the demographics of popular DJs, a public poll hosted by DJ Mag (2014), a popular magazine dedicated to dance music, shows that sixteen out of the top 20 DJs are white. At the 2013 White Wonderland, all the go-go dancers and five of the six DJs were white - the sixth DJ was Laidback Luke, a multiracial Filipino-Dutch DJ. Laidback Luke was one of a handful of nonwhite DJs that my interviewees listed when I asked the question why it seems that most famous DJs seem to be white. Other Asian American DJs they listed included Steve Aoki, Shogun and Ken Loi, while they also pointed to Afrojack as another prominent nonwhite DJ. Nonetheless, the aspect of these discussions important for my analysis was not the actual proportion of successful DJs who are nonwhite but rather the ways in which my interviewees reacted to this question and what these reactions revealed about their understandings of race in the scene. A great number of interviewees were surprised by the question and noted they had never thought about the race of EDM DJs, uttering comments such as "now that I think about it, a lot of DJs are white..." Others were quick to justify this phenomenon and thereby uphold the belief that the EDM festival scene is equally accessible to all races - they noted that the music originated in Europe or turned to reasons why nonwhite groups are not pursuing DJ careers. The latter point relied on dominant racial stereotypes such as that Asian Americans value financial stability and lack creativity, while blacks relate better to hip-hop lyrics focused on urban lower-class lifestyles. In fact, one interviewee pursuing a career as a DJ claimed, "Actually [my Asian American identity] might work to my advantage because there are so little... It's like Jeremy Lin, you know ?" These responses reflected two ways in which dominant racial ideologies were infused with the historical rave ideology adopted by the EDM festival scene; the normalization of whiteness and the denial of racism by invoking culturally based arguments. 


\section{Controlling Authenticity, Belonging and Subcultural Capital}

The normalization of whiteness and denial of racism were also persistent in discussions of the dominant participants in the scene. In the context of an accelerated commercialization of the EDM festival scene in the last few years, informants described a tension between the "kandi ravers" - the most authentic and original attendees-and the "frat bros"- the newcomers who were ruining the PLUR-based culture through their disrespectful behavior. Although they did not always make this connection explicit, a closer analysis reveals that both these groups signify different forms of middle-class whiteness. In analyzing the different forms of whiteness, I adopt Andersen's belief that scholars ought to pay particular attention to the "differentiation among whites" rather than "using whiteness as a monolithic category" (2003: 28). My interviewees identified kandi ravers as white social outcasts from middleclass suburban high schools in surrounding regions. On the other hand, they identified the frat bros as the popular white kids who moved on to participate in the Greek fraternity systems at nearby universities. Although frat bros may more closely approximate popular understandings of middle-class whiteness, signified by their representations of financial, social and cultural capital, ${ }^{12}$ both frat bros and kandi ravers represent forms of middle-class whiteness differentiated by levels of mainstream social acceptance.

When describing the types of participants that she observes at EDM festivals, Vicky, a twenty-year-old Korean American, stated, "I think half of the people that went were like the hardcore rave people, who, when you first think of rave people, the weird white people who wear a lot of kandi and they're very eccentric and... they just kinda look like druggies". Although Vicky was explicit in describing the whiteness of the kandi ravers, most interviewees only noted that kandi ravers tended to be white when prompted about their race, suggesting the normalization of whiteness in discussing the most authentic participants in the scene. My informants expressed complex relationships with the kandi ravers, who were considered to be "losers" in mainstream culture yet also represented the most authentic ravers with access to the subcultural capital within the EDM festival scene. Although my informants did not want to be fully identified as kandi ravers, they seemed to desire partial identification in order to be regarded as authentic "ravers", with the status of "hipness" discussed in previous sections. This partial identification was pronounced in the resentment shared with kandi ravers toward the frat bros, who were invading the scene and jeopardizing the subcultural capital of EDM festivals through their mainstream tendencies.

Vicky described the other "half" of the attendees at EDM festivals as "frat bros and sorority girls", who have recently entered the scene to party, take drugs and find sexual partners. My informants' views of the frat bros and sorority girls were gendered. Their resentment was predominantly directed toward the frat bros for their "obnoxious" and "disrespectful" behavior. The sorority girls, while definitely inauthentic participants in their eyes, were "not hurting anyone [or] taking people's spaces". The frat bros were criticized for pushing, shoving, fighting and generally "having fun at other people's expense"-behaviors considered to be antithetical to the ethos of PLUR. Compared with kandi ravers, interviewees were highly 
conscious of the whiteness of the frat bros, often emphasizing this in their responses. For example, Irene described frat bros as "really, really white. Like the white guys with the tank tops... like the frat tank tops". This emphasis on the whiteness of the frat bros compared to the kandi ravers seems to relate not only to my interviewees' exposure to predominantly white fraternities and sororities in college, but also to their understandings of whiteness being associated with the self-entitled, disrespectful behavior of frat bros. On the other hand, the whiteness of the kandi ravers, the most authentic participants, remained largely invisible.

Asian American participants' discussions of the kandi ravers and frat bros revolve around authenticity and belonging in the EDM festival scene, which are framed as negotiations of different forms of middle-class whiteness. They have come to understand kandi ravers as the embodiment of authenticity and subcultural capital through their loyalty to PLUR and frat bros as the embodiment of the mainstream and cultural capital through their statuses as "popular" and "obnoxious" white men. While my interviewees have turned to the EDM festival scene in order to seek access to subcultural capital and belonging, these ideals are ultimately defined in relation to middle-class whiteness.

\section{Opposition to Urban Black Hip-Hop Culture}

The EDM festival scene not only represents middle-class whiteness, but also represents anti-lower-class blackness through my informant's beliefs that "rave culture" was contrary to their imaginations of urban black hip-hop culture. Toni Morrison (1992) has argued that qualities are attributed to whiteness only in relationship to their absence in a racialized Other. I argue that this definition through inversion also relates to classed understandings of race, as middle-class whiteness is defined in opposition to lowerclass blackness. To my informants, hip-hop culture seems to represent the Other that is antithetical to the middle-class whiteness of EDM festivals. This classed understanding is an important factor behind my informants' beliefs that they can belong in the EDM festival scene through their strategic internalization of the model minority myth, which suggests that Asian Americans are culturally and socioeconomically closer to middleclass whites than other nonwhite groups.

Only a couple of interviewees explicitly expressed middle-classed understandings of EDM festival culture. Responding to why Asian American youth are drawn to EDM festivals, Priya, a twenty-two-year-old Indian American, noted that EDM attracts higherincome groups, implicitly defined as white and Asian American, while her lower-income "black and Mexican friends" were more attracted to rap and hip-hop:

I think especially for me and especially for Asians that I know, most of us are middleor upper-middle-class, so I think it's harder for people to associate to things like rap or hip-hop, which is, you know, mostly talking about struggle... which is probably why you see more of my black and Mexican friends who are into other music like rap and hip-hop. 
She further noted that the ticket prices for EDM festivals are "not cheap", so the events attract a higher income demographic. Through her discussion, Priya points to two ways she believes that class position influences engagement with cultural scenes. First, socioeconomic status influences the types of cultural activities individuals can afford. Second, "class habitus" draws them towards different types of musical and cultural scenes; that is the "long-lasting dispositions of mind and body" derived from the classed experiences of socialization, which in turn shape people's cultural engagements (Bourdieu 1986). When asked whether she associates EDM with the middle- or upper-middle-class, Priya answered, "I think so". Nevertheless, she had trouble explaining exactly what makes EDM seem middle- or upper-middle-class, except that she did not think EDM evoked "struggle" like hip-hop.

Other interviewees also expressed inconsistent racialized and classed understandings of EDM to explain why "Asian American youth are more drawn to EDM than hip-hop music". Nick, a twenty-four-year-old Taiwanese American DJ-in-training, stated that he felt like EDM appeals to Asian American youth because "it's probably easier to relate to than a lot of hip-hop. Like I don't know about selling drugs or gang-banging". Nick implies that most hip-hop music invokes activities associated with the (black) urban lower class which Asian American youth would not relate to, seemingly based on the sweeping assumption that most Asian Americans are middle- or upper-middle-class. Nick further stated that in contrast to hip-hop, EDM is "very international... because there are very little lyrics, or the lyrics are very melodic so it's not really about what the lyrics are... Everyone can hear a good melody, you know ?" At this point, Nick pauses and seems to realize that the idea that everyone can enjoy EDM equally contradicts his earlier statement that he does not see many black participants at EDM festivals. After some hesitation, he states that he does not know why Asian American youth seem to be attracted to EDM. "It could be because there's something about it that other people don't like about it, you know? Like maybe there's something about EDM that black people don't like". Nick's statements reveal how he negotiates the contradiction between his firm belief that EDM is open to all racial groups and his observation that there are few black participants in the scene. Instead of questioning whether EDM may not be as "international" and inclusive as he had claimed, Nick effectively maintains his belief that EDM is not associated with any race by suggesting that blacks simply do not choose to enjoy the music. This again represents an instance of strategic ignorance as Nick seeks to justify his desire to become a popular EDM DJ and believe that he would not encounter racism as an Asian American.

\section{CONCLUSION}

Asian American youth have turned to the EDM festival scene to fill the cultural void created by their status as perpetual foreigners. Yet while EDM festivals, particularly those organized by Insomniac, perpetuate the promise of an egalitarian utopia through the PLUR ideology, both the physical production of the events and the symbolic production of authenticity in 
the scene reflect the dominance of middle-class whiteness. My interviewees' references to this middle-class whiteness were often implicit, reflecting the normalization of whiteness in the EDM festival scene, effectively hidden by the commodified ideology of PLUR. On the other hand, my interviewees described the scene as explicitly antithetical to lower-class blackness, which they believed was encapsulated by what they understood to be hip-hop culture. These discussions served several different strategic interests of the Asian American youth I interviewed, as they justified their participation in the EDM festival scene dominated by middle-class whiteness, associated themselves more closely with middle-class whiteness and disassociated themselves from the oppressions of other nonwhite groups by adhering to cultural racism. My interviewees' discussions of the contemporary EDM festival scene reflected and perpetuated the belief of middle-class whiteness as the desirable norm and lower-class blackness as the undesirable Other.

In this article I have aimed to fill critical gaps at the intersections of cultural studies and Asian American studies. I have argued that previous scholarship on raves and EDM festivals has largely overlooked the opportunity to analyze the disjunction between the egalitarian ideology of raves and dominant ideologies of race and class. Meaningful complements to my study would include the study of race, class, gender or sexuality among other nonmiddle-class-heterosexual-white participants in EDM festivals or other scenes dominated by middle-class whiteness. This article also calls for more research on Asian American youth's engagements with popular and underground cultures, particularly research that adopts a more ethnographic approach given the limited participant observation in my preliminary findings. I have argued that Asian Americans provide a unique lens on the normalization of whiteness in various cultural scenes, as their "perpetual foreigner" status often invokes desires for cultural belonging, while the "model minority" myth characterizes Asian Americans as similarly middle-classed as whites, albeit to advance white interests. I also argue that the current lack of scholarly attention on Asian American youth's cultural engagements further perpetuates the notion that Asian Americans are perpetual foreigners with unique, segregated cultures rather than meaningful participants in cultural scenes, as observed in the EDM festival scene in Southern California.

\section{ACKNOWLEDGEMENTS}

I would like to thank Dr. Sadhana Bery for advising my research. I would also like to thank Dr. Alison Denton Jones and Dr. Chiwen Bao for their advice and encouragement, as well as the Harvard College Research Program for the funding of this research. Lastly, I would like to express my sincere gratitude to each of my interviewees for willingly sharing their experiences and expressing their belief in the value of this study. 


\section{NOTES}

1 Although Electric Daisy Carnival occurs in Las Vegas, I include the event as part of the EDM festival scene in Southern California given its origins in the Greater Los Angeles region and the significant participation from residents of Southern California, according to my interviewees.

2 Kandies are bracelets, necklaces or other accessories made of neon beads that my interviewees believed are a defining symbol of PLUR and "rave culture" in the contemporary EDM festival scene. Kandies are frequently exchanged between two participants that have developed a connection at a festival, following a ritualized handshake simulating each component of PLUR.

3 I define normalization of whiteness as the process in which whiteness has become "the unacknowledged norm [and] the location from which others are defined and judged" (Andersen 2003: 28).

4 See Maira (2002) for an important exception and Lee and Zhou (2004) for a more general discussion of Asian American youth studies.

5 See Hill Collins (1986) for a more thorough discussion of the insider and outsider distinction.

6 Also see Yu 2001; Lee 2005.

7 I refer to "South Asian" and "East Asian" American artists together here, not because I do not acknowledge the important distinctions in their histories and cultures, but because dominant American cultures have largely collapsed the two groups into the category of "Asian Americans".

8 References to Korean pop singer Psy's song "Gangnam Style", which became the most watched video on YouTube in 2012 and Asian American hip hop group Far East Movement's "Like a G6", which achieved number one on the US Billboard Hot 100 for two weeks in November 2010.

9 All interviewee names are pseudonyms throughout the article.

10 Boba is a Taiwanese tea-based drink with chewy tapioca balls that several interviewees claimed "blew up" in Asian American communities several years ago.

$11 \mathrm{~A}$ fob (fresh off the boat) is a colloquial term used to describe an immigrant, typically Asian American, who is perceived not to have assimilated into the American culture, language and behavior.

12 I use social capital to mean one's social networks that have value, and cultural capital to mean one's non-financial social assets, such as education, intellect, speech, or dress, that can increase one's opportunities or life chances. See Bourdieu (1986).

\section{REFERENCES}

Andersen, Margaret L. 2003. "Whitewashing Race: A Critical Review Essay on 'Whiteness”. In White Out: The Continuing Significance of Racism, ed. Ashley Doane and Eduardo BonillaSilva, 21-34. New York: Routledge.

Anderson, Tammy L. 2009. Rave Culture: The Alteration and Decline of a Philadelphia Music Scene. Philadelphia, PA: Temple University Press.

Bailey, Alison. 2007. "Strategic Ignorance”. In Race and Epistemologies of Ignorance, ed. N. Tuana, 77-94. Albany, NY: State University of New York Press. 
Bourdieu, Pierre. 1986. "The Forms of Capital”. In Handbook of Theory and Research for the Sociology of Education, ed. J. Richardson, 241-58. New York: Greenwood.

Buckland, Fiona. 2002. Impossible Dance: Club Culture and Queer World-Making. Middletown, CT: Wesleyan University Press.

Collin, Matthew. 1997. Altered State: The Story of Ecstasy Culture and Acid House. New York: Serpent's Tail.

DJ Mag. “Top 100 DJs”. DJ Mag. 2013. <http://www.djmag.com/top100> (Accessed 1 March 2014).

Fikentscher, Kai. 2000. "You Better Work!" Underground Dance Music in New York City. Hanover, NH: University Press of New England.

Fung, Richard. 2005. "Looking for My Penis: The Eroticized Asian in Gay Video Porn”. In $A$ Companion to Asian American Studies, ed. Kent A. Ono, 235-53. Malden, MA: Blackwell Publishing.

Hill, Andrew. 2002. "Acid House and Thatcherism: Noise, the Mob, and the English Countryside". British Journal of Sociology 53(1): 89-105. <http://dx.doi.org/ 10.1080/00071310120109348>.

Hill Collins, Patricia. 2000. Black Feminist Thought: Knowledge, Consciousness, and the Politics of Empowerment. New York: Routledge.

Hutson, Scott R. 2000. “The Rave: Spiritual Healing in Modern Western Subcultures”. Anthropological Quarterly 73(1): 35-49. <http://www.jstor.org/stable/3317473>.

Kibria, Nazli. 2002. Becoming Asian American: Second-Generation Chinese and Korean American Identities. Baltimore, MD: Johns Hopkins University Press.

Lee, Jennifer, and Min Zhou, eds. 2004. Asian American Youth: Culture, Identity, and Ethnicity. New York: Routledge.

Lee, Robert G. 1999. Orientals: Asian Americans in Popular Culture. Philadelphia: Temple University Press.

Lee, Stacey J. 1996. Unraveling the "Model Minority" Stereotype: Listening to Asian American Youth. New York: Teachers College Press.

--- 2005. Up Against Whiteness: Race, School, and Immigrant Youth. New York: Teachers College Press, Columbia University.

Maira, Sunaina. 2002. Desis in the House: Indian American Youth Culture in New York City. Philadelphia, PA: Temple University Press.

McCall, Tara. 2001. This Is Not a Rave: In the Shadow of a Subculture. Toronto: Insomniac Press. Measham, Fiona. 2001. Dancing on Drugs: Risk, Health and Hedonism in the British Club Scene. London: Free Association.

Morrison, Toni. 1992. Race-ing Justice, En-gendering Power: Essays on Anita Hill, Clarence Thomas, and the Construction of Social Reality. New York: Pantheon.

Reynolds, Simon. 1998. Generation Ecstasy: Into the World of Techno and Rave Culture. 1st ed. Boston, MA: Little, Brown.

Rose, Tricia. 1994. Black Noise: Rap Music and Black Culture in Contemporary America. Hanover, NH: University Press of New England.

Rotella, Pasquale (PasqualeRotella). "Owlie and his supporters spreading the positive vibes at \#EDC! \#peace \#love \#unity \#respect”. 13 April 2014. Tweet (Accessed 9 May 2015). 
Sachs, Elliot. "Diplo Bans Kandi, Pasquale Rotella Responds”. YourEDM, 11 August 2014. <http://www.youredm.com/2014/08/11/diplo-bans-kandi-pasquale-rotella-responds/> (Accessed 9 May 2015).

Silcott, Mireille. 1999. Rave America: New School Dancescapes. Toronto, Ontario: ECW Press.

Thornton, Sarah. 1996. Club Cultures: Music, Media, and Subcultural Capital. 1st U.S. ed. Hanover: University Press of New England.

Yu, Henry. 2001. Thinking Orientals: Migration, Contact, and Exoticism in Modern America. New York: Oxford University Press. 